\title{
Effects of Curing on Green Mold and Stem-End Rot of Citrus Fruit and Its Potential Application Under Florida Packing System
}

\author{
Jiuxu Zhang and Patricia P. Swingle, Florida Department of Citrus, Citrus Research and Education Center, 700 \\ Experiment Station Road, Lake Alfred 33850
}

\begin{abstract}
Zhang, J., and Swingle, P. P. 2005. Effects of curing on green mold and stem-end rot of citrus fruit and its potential application under Florida packing system. Plant Dis. 89:834-840.

The potential of citrus fruit curing for the control of green mold caused by Penicillium digitatum, and the impact of this treatment on stem-end rot caused by Lasiodiplodia theobromae were investigated. The optimum temperatures for mycelial growth of $P$. digitatum and $L$. theobromae were about 25 and $30^{\circ} \mathrm{C}$, respectively. $P$. digitatum did not grow at $35^{\circ} \mathrm{C}$, while L. theobromae did. Injuries of 'Valencia' oranges developed less green mold disease at 30 and $35^{\circ} \mathrm{C}$ than at $25^{\circ} \mathrm{C}$ or lower. Green mold incidences on 'Valencia' oranges treated at $21^{\circ} \mathrm{C}$ (uncured control), 30 and $35^{\circ} \mathrm{C}$ for $48 \mathrm{~h}$ were $51,17.4$, and $0 \%$, respectively, for inoculated fruit, and $18.8,11.4$, and $0 \%$, respectively, for wounded fruit after 2 weeks of storage at $21^{\circ} \mathrm{C}$. However, a significant increase in stem-end rot occurred at $35^{\circ} \mathrm{C}$ when compared with $21^{\circ} \mathrm{C}$ (uncured control). In two of three different tests, curing fruit at $35^{\circ} \mathrm{C}$ for $48 \mathrm{~h}$ achieved better green mold control than a shorter curing time of $24 \mathrm{~h}$. Curing 'Pineapple' oranges showed a similar or better efficacy for green mold control than imazalil at 500 and $1,000 \mathrm{ppm}$ applied by either dip or packingline drip. The combination of thiabendazole drench $(500 \mathrm{ppm})$ and curing of wounded 'Valencia' oranges and inoculated 'Flame' grapefruit reduced both green mold and stem-end rot by more than $93 \%$. This study suggests that curing $\left(35^{\circ} \mathrm{C}\right.$ for $\left.48 \mathrm{~h}\right)$ could be integrated into the current Florida citrus packing system to effectively control postharvest decays.
\end{abstract}

Additional keywords: Botryodiplodia theobromae, Diplodia natalensis, ethylene degreening, postharvest disease, postharvest handling

Green mold, caused by Penicillium digitatum (Pers.:Fr.) Sacc., is one of the leading postharvest decays on Florida citrus fruit, and it is also a common postharvest disease of citrus throughout the world $(10,18)$. This fungus only infects fruit through fruit injuries created by harvesting and subsequent handling. Stem-end rot, caused by Lasiodiplodia theobromae (Pat.) Griffon \& Maubl. (syn. Diplodia natalensis Pole-Evans and Botryodiplodia theobromae Pat.; teleomorph Botryosphaeria rhodina (Cooke) Arx), is an important postharvest disease in warm and humid citrus growing regions such as Florida (5). All citrus cultivars are susceptible to this disease. The incidence and severity of stem-end rot can be greatly increased by ethylene degreening treatment, which is used to improve fruit peel color in growing regions where natural color break is delayed by persistent high temperatures (5). In Florida, the commercial control of green mold, stem-end rot, and other postharvest decays is conducted by an integrated pro-

Corresponding author: Jiuxu Zhang

E-mail: jzhang@ citrus.state.fl.us

Accepted for publication 31 March 2005.

DOI: 10.1094/PD-89-0834

(C) 2005 The American Phytopathological Society cedure with fungicides as the core component $(7,21)$. Due to increasingly restrictive regulations, environmental and health concerns, and pathogen resistance development, alternatives to chemicals for citrus postharvest decay control are needed. Nonchemical methods such as heat treatment might be developed to effectively control certain diseases or to serve as an important component in an integrated system for postharvest decay control.

Curing, as a type of heat treatment method for citrus postharvest decay control, was reported in the early twentieth century $(11,12)$. In Florida, commercial packinghouses usually degreen earlyseason fruit (September to December) with ethylene at 28 to $30^{\circ} \mathrm{C}$ and 90 to $96 \%$ relative humidity $(\mathrm{RH})$ to achieve market acceptance of the color $(14,25)$. The conditions of this practice can result in a significant increase in certain postharvest diseases such as stem-end rot, but a decrease in other diseases such as green mold $(1,15)$. Hopkins and Loucks (15) reported that early in the Florida citrus fruit season, when fruit were being degreened for 60 to $70 \mathrm{~h}$, the stem-end rot incidence was higher because of the debilitating effect of ethylene, while mold infections were low due to the curing effect of the higher temperatures of degreening conditions. Later in the season, when degreening was discontinued or greatly reduced, there was a sharp drop in stem-end rot and a marked increase in mold. Ben-Yehoshua et al. (2) showed that curing of seal-packaged and $P$. digitatum inoculated 'Eureka' lemons at $36^{\circ} \mathrm{C}$ for 3 days effectively reduced green mold during nearly 2 months of storage at $17^{\circ} \mathrm{C}$. Stange and Eckert (24) demonstrated that 18 -h-old infections of $P$. digitatum on California lemon fruit could be eradicated by curing at $32^{\circ} \mathrm{C}$ for 36 to 48 $\mathrm{h}$, and in some of their experiments, decay control by curing for $48 \mathrm{~h}$ was equivalent to control achieved by the fungicide imazalil at 1,000 ppm. Plaza et al. (20) reported that curing 'Navelina' and 'Salustiana' oranges at $33^{\circ} \mathrm{C}$ for $65 \mathrm{~h}$ effectively controlled both green and blue mold development on artificially inoculated and naturally infected oranges stored at $20^{\circ} \mathrm{C}$ for 7 days. However, when the cured fruit were stored at $4^{\circ} \mathrm{C}$ for 2 months followed by 7 days at $20^{\circ} \mathrm{C}$, green mold, but not blue mold, was significantly reduced (20).

Although the curing treatment of citrus fruit is actually practiced during degreening treatment in Florida packinghouses, the optimum curing conditions for green mold control have not been determined. There is a little information regarding the influence of high temperature alone on stem-end rot, although the stimulation of this disease by ethylene degreening treatment has been well documented $(1,6,15)$. Since curing with elevated temperatures might have both positive and negative effects on citrus postharvest decays, an integrated procedure that includes curing treatment could be more practical for effective postharvest decay control of Florida citrus.

The objectives of this study were to: (i) determine the effects of temperature on the mycelial growth of $P$. digitatum and $L$. theobromae; (ii) develop optimum curing conditions for green mold control; (iii) evaluate the influence of curing conditions on stem-end rot; and (iv) determine if a combination of fungicide and curing treatments would control both green mold and stem-end rot in the Florida packing system.

\section{MATERIALS AND METHODS}

Pathogens and fungicides. A $P$. digitatum strain (PD-9) and an L. theobromae strain (D-11) were isolated from decayed citrus fruit and used in these tests. The cultures of $P$. digitatum and $L$. theobromae were initiated by using cultures of a single spore and a hyphal tip, respectively. The 
pathogens were maintained in potato dextrose agar (PDA) slants in test tubes stored at $4{ }^{\circ} \mathrm{C}$. The fungal pathogenicity and virulence were maintained by inoculating citrus fruit with the fungi and reisolating them yearly.

Commercial citrus postharvest fungicides thiabendazole (TBZ) $(95 \%$ wettable powder, Freshgard 598, FMC Inc., Lakeland, FL) and imazalil (44.4\% EC, Freshgard 700, FMC) were used.

Inoculum preparation of $\boldsymbol{P}$. digitatum. Prior to each inoculation in various tests, $P$. digitatum was recovered from PDA slants in storage and grown in $9-\mathrm{cm}$ plates with PDA at $25^{\circ} \mathrm{C}$ for 7 to 10 days. Spores were harvested from a PDA plate by adding about $8 \mathrm{ml}$ of sterile water with $0.05 \%$ Triton X-100 and rubbing the fungal colony with a sterile glass rod. The spore suspension was filtered through two layers of sterile cheesecloth to remove the mycelia and medium particles, and diluted with sterile water to an absorbance of 0.1 at 420 $\mathrm{nm}$ using a spectrophotometer (Model UV 160U, Shimadzu Inc., Columbia, MD). This density of the spore suspension was equivalent to a concentration of approximately $10^{6}$ spores per $\mathrm{ml}(9,23)$. The spore concentration was confirmed using a hemacytometer to determine actual spore counts of the suspension. Other researchers (9) established the correlation of $P$. digitatum spore concentration in suspension to its optical density by comparison of a series of standard spore suspensions with hemacytometer counts.

Fruit. Oranges (Citrus sinensis (L.) Osbeck 'Valencia' and 'Pineapple') and grapefruit (C. paradisi Macfad. 'Flame') were purchased from a local commercial packinghouse (Hunt Brothers, Lake Wales, FL) and brought to the Citrus Research and Education Center (Lake Alfred, FL). Fruit were used in various tests within 24 to $48 \mathrm{~h}$ of arrival at the research facility.

Effects of temperature on the mycelial growth of $P$. digitatum and $L$. theobromae. Separate incubators were set to temperatures of $10,20,25,30,35$, and $40^{\circ} \mathrm{C}$, respectively, prior to the tests. $P$. digitatum and $L$. theobromae were cultured on PDA plates at $25^{\circ} \mathrm{C}$ for 4 and 2 days, respectively. A 5-mm PDA disk with fungal mycelia cut from the edge of the fungal colony was transferred onto the center of a plate ( $9 \mathrm{~cm}$ diameter) containing about 18 $\mathrm{ml}$ of PDA. The plates were incubated at the range of temperatures described above. Five plates were used for each fungus and temperature. Fungal colony diameters of $L$. theobromae and $P$. digitatum were recorded at 1 and 4 days, respectively. The fungal mycelial growth was expressed by the colony diameter measurements minus the originally inoculated PDA disk diameter $(5 \mathrm{~mm})$. The experiment was repeated.

Effect of temperature on the development of green mold on injured fruit. 'Valencia' fruit were aseptically wounded to create injuries, $3 \mathrm{~mm}$ in diameter and 3 $\mathrm{mm}$ in depth, using a cork borer. The wounded fruit were placed in covered dishpans containing wet paper towels $(100 \% \mathrm{RH})$ and incubated at 10, 15, 20, 25,30 , and $35^{\circ} \mathrm{C}$, respectively. After $24 \mathrm{~h}$ of incubation, one group of the fruit from each treatment was inoculated by placing $20 \mu \mathrm{l}$ of $P$. digitatum spore suspension $\left(10^{6}\right.$ spores per ml) into each wound site. Another group of fruit was inoculated $48 \mathrm{~h}$ after incubation. All inoculated fruit were then placed back in the same dishpans and incubated at $25^{\circ} \mathrm{C}$. Green mold incidence was recorded after 4 days. Three replicates were used in each treatment, and 10 fruit were used in each replication. The disease development was used to assess the infections of injuries by $P$. digitatum after the injuries were treated with different temperatures. The test was repeated.

Fruit wounding and inoculation. In different tests described below, the fruit were treated in one of three ways: (i) Natural injury and infections: Fruit injuries resulted from harvest and subsequent postharvest handling, and both $L$. theobromae and $P$. digitatum were from natural inoculum sources. (ii) Artificial injury and natural infections: A wound, $2 \mathrm{~mm}$ in diameter and $3 \mathrm{~mm}$ in depth, was made on each fruit by puncturing fruit with a round metal probe, and both $P$. digitatum and L. theobromae infections were from natural inoculum sources. (iii) Artificial injury and inoculation of fruit with $P$. digitatum: Fruit were punctured with a probe with a $1 \times 1$ $\mathrm{mm}$ tip that had been dipped into $P$. digitatum spore suspension $\left(10^{6}\right.$ spores per $\left.\mathrm{ml}\right)$ immediately before use. One inoculation site was established on each fruit. In this current study, fruit were never artificially inoculated with $L$. theobromae, and all $L$. theobromae infections were from latent infections. Natural levels of $L$. theobromae latent infections are affected by a variety of factors, such as the age of citrus trees, cultural practices, preharvest chemical sprays, and different harvesting times among various groves, giving a background level of stem-end rot that was variable between tests.

Effects of curing temperature on green mold and stem-end rot. Green mold was the target disease of these curing treatments, but the effect on stem-end rot was also documented. Based on the test results of the effects of temperature on $P$. digitatum mycelial growth and the development of disease on injured fruit described previously, temperatures of 30 and $35^{\circ} \mathrm{C}$, and a curing duration of $48 \mathrm{~h}$, were chosen to test the effects of curing temperature using wounded or 24-hpostinoculated 'Valencia' oranges. The temperature of $21^{\circ} \mathrm{C}$ was used as a control to simulate ambient packinghouse temperature. $\mathrm{RH}$ of at least $95 \%$ was maintained for all tests. For each test, there were three treatments, with three replicates of 50 to 70 fruit for each treatment. After curing treatments, fruit were stored at $21^{\circ} \mathrm{C}$ with approximately $95 \% \mathrm{RH}$ for 2 weeks, and decay incidences were recorded weekly. Temperature and HR in the storage room were controlled by a thermostat (Honeywell Inc., Minneapolis, MN) and a humistat (American Instrument, Silver Spring, MD) system, respectively. The temperature control system was set at required levels with variations of $\pm 0.5^{\circ} \mathrm{C}$. Temperature and RH in all tests were monitored with Ryan Hat Unit 33384 (Sensitech Inc., Redmond, WA) and recorded automatically every $10 \mathrm{~min}$. The test was repeated.

Effects of curing duration on green mold and stem-end rot. Two tests using 'Valencia' oranges were conducted to determine the optimum curing duration at $35^{\circ} \mathrm{C}$, with 95 to $100 \% \mathrm{RH}$ for green mold and stem-end rot control. The duration of curing for test 1 was $0,24,36$, or $48 \mathrm{~h}$ using $P$. digitatum-inoculated 'Valencia' oranges. In test 2 , the curing duration was $0,24,48$, or $72 \mathrm{~h}$ using noninoculated 'Valencia' oranges. After curing treatment at $35^{\circ} \mathrm{C}$ for the various time intervals described above, the fruit were maintained at $21^{\circ} \mathrm{C}$ with about $95 \%$ RH. Disease incidences of green mold and stem-end rot were recorded weekly for up to 2 weeks for test 1 , and up to 4 weeks for test 2 .

Comparison of efficacy of curing to imazalil for green mold and stem-end rot control. $P$. digitatum-inoculated 'Pineapple' orange fruit and two methods of imazalil application were used in the tests: (i) Dip method: 24-h-postinoculated fruit were dipped in imazalil solutions at 250 , 500 , or $1,000 \mathrm{ppm}$ for $1 \mathrm{~min}$, and then stored at $21^{\circ} \mathrm{C}$ for 2 weeks. Fruit curing treatment was conducted by incubating inoculated fruit ( $24 \mathrm{~h}$ postinoculation) at $35^{\circ} \mathrm{C}$ for $48 \mathrm{~h}$ with at least $95 \% \mathrm{RH}$, and then maintaining the fruit at $21^{\circ} \mathrm{C}$ for 2 weeks. Inoculated fruit dipped in water at $21^{\circ} \mathrm{C}$ for $1 \mathrm{~min}$ followed by the incubation at $21^{\circ} \mathrm{C}$ served as controls. (ii) Packingline drip method: 24-h-postinoculated fruit were dripped with imazalil solutions at 250,500 , or $1,000 \mathrm{ppm}$ for 15 to $20 \mathrm{~s}$ on a simulated commercial packingline. Treated fruit were dried at approximately $52^{\circ} \mathrm{C}$ for 1 to $2 \mathrm{~min}$, and then incubated at $21^{\circ} \mathrm{C}$ for 2 weeks. Inoculated fruit dripped with water and then incubated at $21^{\circ} \mathrm{C}$ served as controls. Another group of inoculated fruit were cured at $35^{\circ} \mathrm{C}$ with at least $95 \% \mathrm{RH}$ for $48 \mathrm{~h}$, and then incubated at $21^{\circ} \mathrm{C}$ for 2 weeks. Three replicates were used for each treatment, and each replicate had 40 to 50 fruit.

Efficacy of TBZ drench and curing on green mold and stem-end rot control. To simulate the commercial drench application used in Florida packinghouses, a small drench system was constructed and used in the tests. The system consisted of a solution container, showerhead, two pumps, 


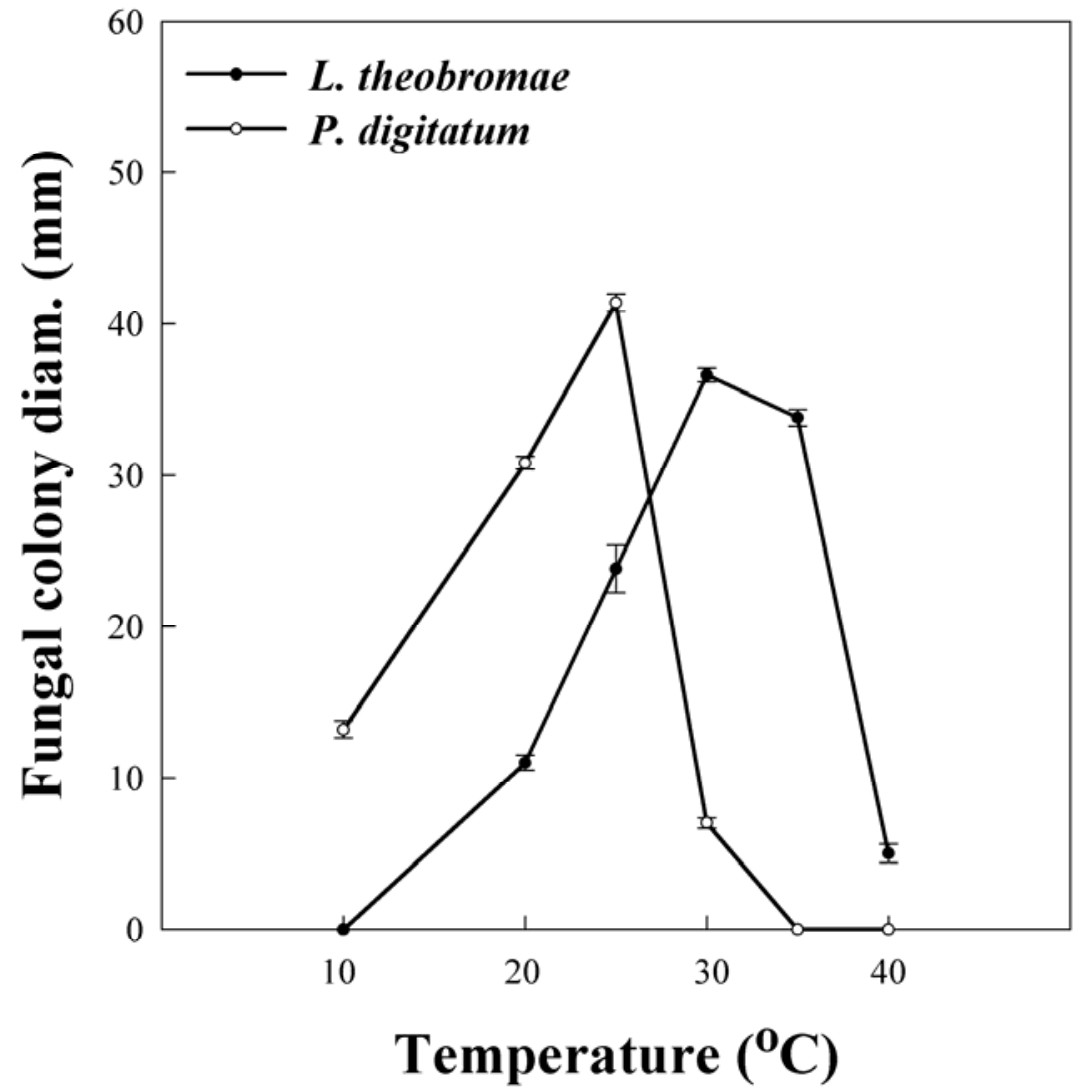

Fig. 1. Effects of temperature on mycelial growth of Lasiodiplodia theobromae and Penicillium digitatum on potato dextrose agar at 1 and 4 days, respectively. Vertical bars represent standard errors of means calculated from five replicates.

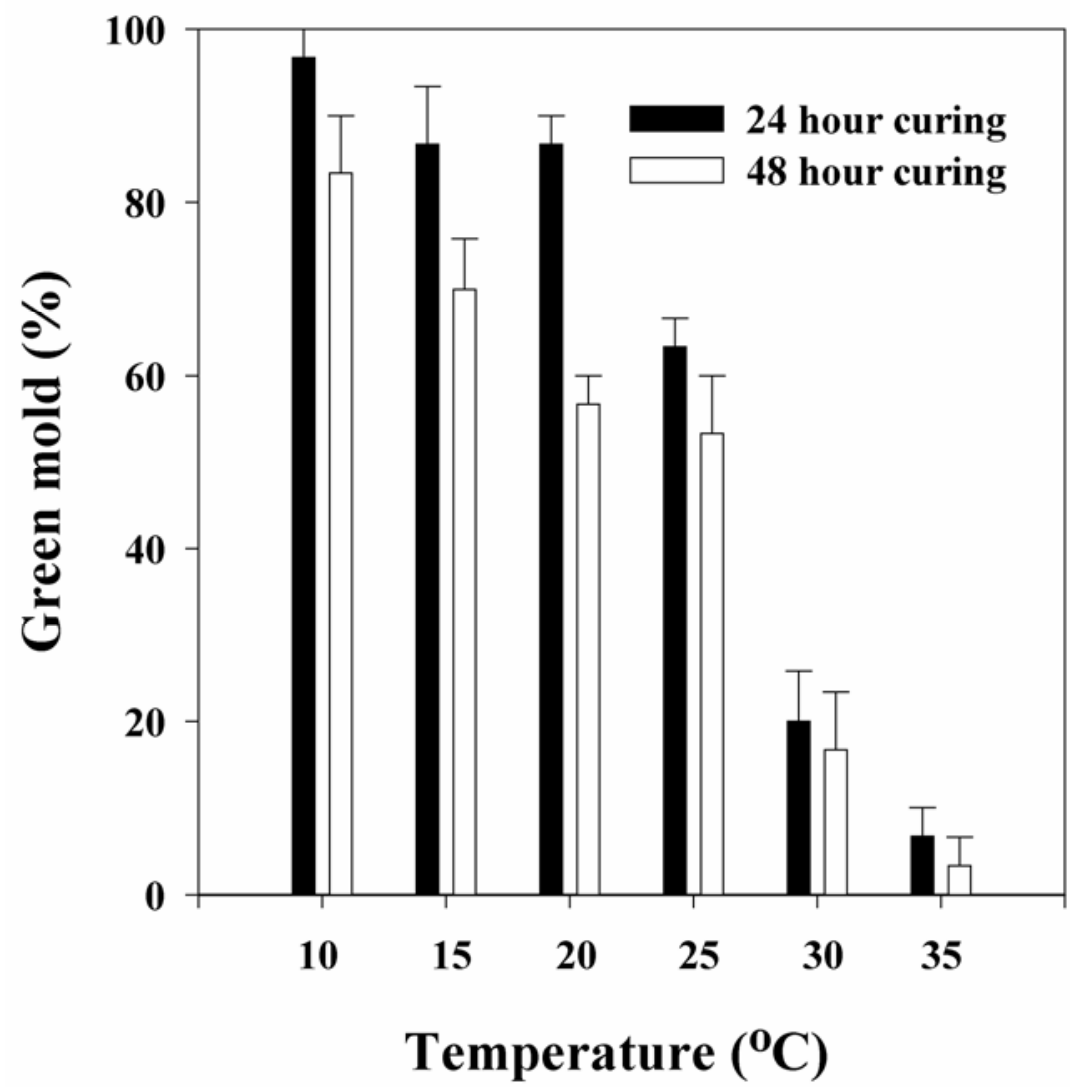

Fig. 2. Effects of temperature and time on the development of green mold on injured 'Valencia' oranges. Injured fruit were cured for 24 or $48 \mathrm{~h}$ before inoculation, and all fruit were stored at $25^{\circ} \mathrm{C}$ after inoculation for up to 4 days. Standard errors from three replicates are expressed on each of the bars. tubes, and a plastic support frame. The two pumps circulated the drench solutions throughout the system. The showerhead delivered the drench solutions to the fruit. About 40 liters of the solution were used in a drench cycle. Flow rate was approximately 20 liters/min. Two tests were conducted. Wounded $(2 \times 3 \mathrm{~mm})$ 'Valencia' fruit were used in one test, and $P$. digitatum-inoculated 'Flame' grapefruit were used in the other test. 'Valencia' oranges or 'Flame' grapefruit were placed into plastic crates $(60 \times 40 \times 30 \mathrm{~cm})$. Three crates were stacked on top of each other as a treatment to simulate a commercial drench procedure. Fruit were drenched with TBZ solution $(500 \mathrm{ppm})$ for $3 \mathrm{~min}$ and drained for 4 min (commercial standard practice) prior to curing treatment. Fruit without drench and curing served as controls. Three replications were used for each treatment. Each replicate had 70 'Valencia' oranges or 40 'Flame' grapefruit. Drenched fruit were then cured for $48 \mathrm{~h}$ at $35^{\circ} \mathrm{C}$ and 95 to $100 \% \mathrm{RH}$. After curing, fruit were stored at $21^{\circ} \mathrm{C}$, and incidence of decay was recorded weekly for up to 3 weeks.

Data analysis. Percent decay data were transformed to arcsine values before analysis. Analysis of variance of data was performed using the Statistica program (StatSoft, Tulsa, OK). Treatment means were compared using Duncan's multiple range test $(P=0.05)$. Actual disease incidences were used in the second figure and all tables.

\section{RESULTS}

Effects of temperature on the mycelial growth of $P$. digitatum and $L$. theobromae. Between 10 to $40^{\circ} \mathrm{C}, P$. digitatum growth increased with temperature from 10 to $25^{\circ} \mathrm{C}$, declined sharply from 25 to $30^{\circ} \mathrm{C}$, and dropped to zero at $35^{\circ} \mathrm{C}$ (Fig. 1). The optimum growth temperature for $P$. digitatum was about $25^{\circ} \mathrm{C}$ within the temperatures tested. The mycelial growth of $L$. theobromae increased from 10 to $30^{\circ} \mathrm{C}$, and decreased slightly from 30 to $35^{\circ} \mathrm{C}$, and then sharply declined from 35 to $40^{\circ} \mathrm{C}$ (Fig. 1). In repeated tests, the optimum temperature for $L$. theobromae growth was $30^{\circ} \mathrm{C}$ in the temperatures tested.

Effect of temperature on the development of green mold on injured fruit. The development of green mold declined as the initial incubating temperature increased from 10 to $35^{\circ} \mathrm{C}$ (Fig. 2). The wounds that were incubated at 30 or $35^{\circ} \mathrm{C}$ for 24 or $48 \mathrm{~h}$ before inoculation showed a much lower disease level compared with those that were incubated at $10,15,20$, or $25^{\circ} \mathrm{C}$. The test was repeated with similar results.

Effects of curing temperature on green mold and stem-end rot. In the wounded fruit test, after 2 weeks of storage at $21^{\circ} \mathrm{C}$ following curing, green mold incidence was reduced by 39.4 and $100 \%$ 
when fruit were cured at 30 and $35^{\circ} \mathrm{C}$, respectively, for $48 \mathrm{~h}$ compared with the uncured controls $\left(21^{\circ} \mathrm{C}\right)$ (Table 1). For the inoculated fruit test, curing fruit at 30 and $35^{\circ} \mathrm{C}$ for $48 \mathrm{~h}$ followed by 2 weeks of storage at $21^{\circ} \mathrm{C}$ reduced green mold by 65.9 and $100 \%$, respectively, compared ever, curing wounded fruit at $35^{\circ} \mathrm{C}$, but not at $30^{\circ} \mathrm{C}$, for $48 \mathrm{~h}$ followed by 2 weeks of storage at $21^{\circ} \mathrm{C}$ significantly $(P=0.05)$ increased stem-end rot incidence when compared with uncured fruit $\left(21^{\circ} \mathrm{C}\right)$ (Table 1). For inoculated fruit, curing at 30 and $35^{\circ} \mathrm{C}$ also significantly enhanced stem-end rot compared with uncured control fruit $\left(21^{\circ} \mathrm{C}\right)$.

Effects of curing duration on green mold and stem-end rot. Twenty-four hours after 'Valencia' fruit inoculation with $P$. digitatum, the fruit were cured at $35^{\circ} \mathrm{C}$ with at least $95 \% \mathrm{RH}$ for $0,24,36$, and $48 \mathrm{~h}$. Evaluation of the fruit following 2 weeks of storage at $21^{\circ} \mathrm{C}$ revealed that green mold incidence was reduced by 39.6 , with uncured control fruit $\left(21^{\circ} \mathrm{C}\right)$. How-

86.7, and $95.7 \%$ for 24,36 , and $48 \mathrm{~h}$ of curing, respectively, when compared with control fruit (Table 2). Curing fruit for 36 or $48 \mathrm{~h}$ was significantly better than a curing duration of $24 \mathrm{~h}$ for green mold control, and no significant difference was found between 36 and $48 \mathrm{~h}$ of curing. The incidence of stem-end rot was also recorded in this test, resulting from natural infections of $L$. theobromae. Curing at $35^{\circ} \mathrm{C}$ for 24 to $48 \mathrm{~h}$ significantly increased the incidence of stem-end rot after 2 weeks.

When noninoculated 'Valencia' oranges were cured at $35^{\circ} \mathrm{C}$ and at least $95 \% \mathrm{RH}$ for $0,24,48$, and $72 \mathrm{~h}$, green mold was significantly reduced by curing for 24 to $72 \mathrm{~h}$ during 4 weeks of storage at $21^{\circ} \mathrm{C}$ after curing (Table 3). Curing for 48 or 72 $h$ was better than a curing period of $24 \mathrm{~h}$, and no significant difference in green mold control between 48 and $72 \mathrm{~h}$ was observed at 1 to 4 weeks of storage at $21^{\circ} \mathrm{C}$ after curing treatment. However, curing fruit at $35^{\circ} \mathrm{C}$ for 48 to $72 \mathrm{~h}$, but not for $24 \mathrm{~h}$, sig-

Table 1. Effects of curing temperature on green mold and stem-end rot of 'Valencia' oranges

\begin{tabular}{lccccc}
\hline & \multicolumn{2}{c}{ Cumulative green mold (\%) } & & \multicolumn{2}{c}{ Cumulative stem-end rot (\%) } \\
\cline { 2 - 3 } Treatment & Week 1 & Week 2 & & Week 1 & Week 2 \\
\hline Wounded fruit & $12.8 \mathrm{a}^{\mathrm{z}}$ & $18.8 \mathrm{a}$ & & $9.6 \mathrm{a}$ & $37.5 \mathrm{~b}$ \\
Uncured controls kept at $21^{\circ} \mathrm{C}$ & $5.3 \mathrm{~b}$ & $11.4 \mathrm{~b}$ & & $16.3 \mathrm{a}$ & $41.3 \mathrm{ab}$ \\
$30^{\circ} \mathrm{C}$ & $0 \mathrm{c}$ & $0 \mathrm{c}$ & & $16.1 \mathrm{a}$ & $48.7 \mathrm{a}$ \\
$35^{\circ} \mathrm{C}$ & & & & & \\
Inoculated fruit & $47.4 \mathrm{a}$ & $51.0 \mathrm{a}$ & & $5.2 \mathrm{~b}$ & $7.0 \mathrm{~b}$ \\
Uncured controls kept at $21^{\circ} \mathrm{C}$ & $10.6 \mathrm{a}$ & $17.4 \mathrm{~b}$ & & $15.5 \mathrm{a}$ & $31.0 \mathrm{a}$ \\
$30^{\circ} \mathrm{C}$ & $0 \mathrm{c}$ & $0 \mathrm{c}$ & $12.1 \mathrm{a}$ & $30.1 \mathrm{a}$ \\
$35^{\circ} \mathrm{C}$ & &
\end{tabular}

${ }^{x}$ Stored at $21^{\circ} \mathrm{C}$.

${ }^{y}$ Curing temperatures were 30 and $35^{\circ} \mathrm{C}$ for $48 \mathrm{~h}$ for all fruit except controls, which were maintained at $21^{\circ} \mathrm{C}$.

${ }^{\mathrm{z}}$ Means with the same letter in the same column and test are not significantly different based on Duncan's multiple range test $(P=0.05)$.

Table 2. Effects of curing duration on green mold and stem-end rot of 'Valencia' oranges

\begin{tabular}{lccccc}
\hline & \multicolumn{2}{c}{ Cumulative green mold (\%) } & & \multicolumn{2}{c}{ Cumulative stem-end rot (\%) } \\
\cline { 2 - 3 } \cline { 5 - 6 } Treatment $^{\mathbf{y}}$ & Week 1 & Week 2 & & Week 1 & Week 2 \\
\hline Control (no curing) & $80.0 \mathrm{a}^{\mathrm{z}}$ & $89.3 \mathrm{a}$ & & $2.9 \mathrm{a}$ & $3.9 \mathrm{~b}$ \\
Curing 24 h & $4.8 \mathrm{~b}$ & $53.9 \mathrm{~b}$ & & $6.9 \mathrm{a}$ & $12.7 \mathrm{a}$ \\
Curing 36 h & $0.5 \mathrm{~b}$ & $11.9 \mathrm{c}$ & & $7.6 \mathrm{a}$ & $20.1 \mathrm{a}$ \\
Curing 48 h & $0 \mathrm{~b}$ & $3.8 \mathrm{c}$ & & $8.6 \mathrm{a}$ & $20.5 \mathrm{a}$ \\
\hline
\end{tabular}

${ }^{x}$ Stored at $21^{\circ} \mathrm{C}$ after curing treatment; green mold was inoculated while stem-end rot was from field infections.

${ }^{y}$ Curing temperature was $35^{\circ} \mathrm{C}$ for all fruit except controls, which were maintained at $21^{\circ} \mathrm{C}$.

${ }^{z}$ Means with the same letter in the same column are not significantly different based on Duncan's multiple range test $(P=0.05)$. nificantly increased the incidence of stemend rot when fruit were evaluated after 4 weeks of storage at $21^{\circ} \mathrm{C}$ following the curing treatment (Table 3 ).

Comparison of efficacy of curing to imazalil for green mold and stem-end rot control. The efficacy of curing for green mold control was compared with that of imazalil using two application methods and $P$. digitatum-inoculated 'Pineapple' oranges. In a dip application, curing at $35^{\circ} \mathrm{C}$ for $48 \mathrm{~h}$ and imazalil at 250,500 , or $1,000 \mathrm{ppm}$ significantly reduced green mold incidence at 1 to 2 weeks of storage at $21^{\circ} \mathrm{C}$ after the different treatments (Table 4). Curing performed better than imazalil at the rate of $250 \mathrm{ppm}$ for green mold control and showed a similar efficacy to that of imazalil at rates of 500 and 1,000 ppm. However, cured fruit had a significantly increased incidence of stem-end rot compared with those of the control and imazalil-treated fruit at 250, 500 , or $1,000 \mathrm{ppm}$ levels. Similar results of curing versus imazalil were observed when imazalil was applied using a simulated commercial drip method through a packingline (Table 4).

Efficacy of TBZ drench and curing on green mold and stem-end rot control. Using wounded 'Valencia' oranges to evaluate the efficacy of the combination of TBZ drench and curing for the control of both green mold and stem-end rot, Table 5 shows that curing treatment alone significantly reduced green mold incidence but increased the incidence of stem-end rot. In addition, $L$. theobromae wound infections on cured fruit were about two times higher than those on noncured fruit (J. Zhang, unpublished). However, when fruit were drenched with TBZ (500 ppm) first, then cured at $35^{\circ} \mathrm{C}$ and at least $95 \% \mathrm{RH}$ for $48 \mathrm{~h}$, the incidences of both green mold and stemend rot were reduced from 29.6 and $10.9 \%$ to 0.3 and $0.7 \%$, respectively, after 3 weeks of storage at $21^{\circ} \mathrm{C}$ following curing.

When $P$. digitatum-inoculated 'Flame' grapefruit were used in a similar test, green mold incidence was also significantly reduced by curing, TBZ drench, or TBZ drench plus curing (Table 6). Stem-end rot occurred at a very low level in all treatments in this test $(0$ to $2.5 \%)$. TBZ drench and TBZ drench plus curing reduced both green mold and stem-end rot to a minimal level (Table 6).

Table 3. Effects of curing duration on green mold and stem-end rot using naturally infected 'Valencia' oranges

\begin{tabular}{|c|c|c|c|c|c|c|c|c|}
\hline \multirow[b]{2}{*}{ Treatment $^{\mathbf{y}}$} & \multicolumn{4}{|c|}{ Cumulative green mold $(\%)^{x}$} & \multicolumn{4}{|c|}{ Cumulative stem-end rot $(\%)$} \\
\hline & Week 1 & Week 2 & Week 3 & Week 4 & Week 1 & Week 2 & Week 3 & Week 4 \\
\hline Control & $4.5 \mathrm{a}^{\mathrm{z}}$ & $8.0 \mathrm{a}$ & $9.7 \mathrm{a}$ & $12.1 \mathrm{a}$ & $10.5 \mathrm{~b}$ & $40.4 \mathrm{a}$ & $52.6 \mathrm{c}$ & $59.8 \mathrm{~b}$ \\
\hline Curing $24 \mathrm{~h}$ & $0 \mathrm{~b}$ & $1.8 \mathrm{~b}$ & $2.8 \mathrm{~b}$ & $2.8 \mathrm{~b}$ & $9.0 \mathrm{~b}$ & $40.2 \mathrm{a}$ & $55.6 \mathrm{abc}$ & $68.2 \mathrm{ab}$ \\
\hline Curing $48 \mathrm{~h}$ & $0 \mathrm{~b}$ & $0 \mathrm{c}$ & $0 \mathrm{c}$ & $0.3 \mathrm{c}$ & $19.6 \mathrm{a}$ & $49.1 \mathrm{a}$ & $68.6 \mathrm{ab}$ & $79.6 \mathrm{a}$ \\
\hline Curing $72 \mathrm{~h}$ & $0 \mathrm{~b}$ & $0 \mathrm{c}$ & $0 \mathrm{c}$ & $0.7 \mathrm{c}$ & $18.3 \mathrm{a}$ & $45.3 \mathrm{a}$ & $61.7 \mathrm{ac}$ & $74.3 \mathrm{a}$ \\
\hline
\end{tabular}

${ }^{\mathrm{x}}$ Stored at $21^{\circ} \mathrm{C}$ after curing.

${ }^{y}$ Curing at $35^{\circ} \mathrm{C}$.

${ }^{\mathrm{z}}$ Means with the same letter in the same column are not significantly different based on Duncan's multiple range test $(P=0.05)$. 


\section{DISCUSSION}

Curing fruit as an effective method for the control of green mold on citrus fruit has been previously reported $(2,15,20,24)$. In the current study, curing of 'Valencia' and 'Pineapple' oranges and 'Flame' grapefruit at 30 to $35^{\circ} \mathrm{C}$ for $24 \mathrm{~h}$ or longer significantly reduced green mold incidence, and the optimum conditions for curing Florida 'Valencia' oranges and 'Flame' grapefruit appear to be $35^{\circ} \mathrm{C}$ with 95 to $100 \% \mathrm{RH}$ for $48 \mathrm{~h}$ (Tables 1 to 3 ). These conditions might not be suitable for 'Pineapple' oranges due to the development of peel disorders during the subsequent 2 weeks of storage at $21^{\circ} \mathrm{C}$ that appeared to have been induced by the curing temperature $\left(35^{\circ} \mathrm{C}\right)$ (J. Zhang, unpublished). Plaza et al. (20) suggested that curing conditions for 'Navelina' and 'Salustiana' oranges were $33^{\circ} \mathrm{C}$ for $65 \mathrm{~h}$. Strange and Eckert (24) recommended the conditions of $32^{\circ} \mathrm{C}$ for 36 to $48 \mathrm{~h}$ for California lemon fruit. In Florida early season (September to December), fruit are often subjected to ethylene treatment to remove the chlorophyll and thus reveal the orange coloration necessary to meet market acceptance $(13,15)$. The degreening conditions in Florida are 28 to $30^{\circ} \mathrm{C}, 90$ to $96 \% \mathrm{RH}$, and 5 ppm of ethylene (25). Essentially, these conditions are also a curing treatment for green mold control. This could largely explain why green mold is not a problem on early season fruit. Based on this information, Hopkins and Loucks (15) recommended that Florida fruit should be cured at $30^{\circ} \mathrm{C}$ throughout the entire fruit season

Table 4. Comparison of efficacy of curing to imazalil for green mold and stem-end rot control using 'Pineapple' oranges

\begin{tabular}{lccccc}
\hline & \multicolumn{2}{c}{ Cumulative green mold (\%) } & & \multicolumn{2}{c}{ Cumulative stem-end rot (\%) } \\
\cline { 2 - 2 } \cline { 5 - 6 } Treatment & Week 1 & Week 2 & & Week 1 & Week 2 \\
\hline Dip method & & & & & \\
Control $\left(21^{\circ} \mathrm{C}\right)$ & $60.8 \mathrm{a}^{\mathrm{y}}$ & $85.6 \mathrm{a}$ & & $0 \mathrm{~b}$ & $1.9 \mathrm{~b}$ \\
Curing $\left(35^{\circ} \mathrm{C} \text { for } 48 \mathrm{~h}\right)^{\mathrm{z}}$ & $0 \mathrm{bc}$ & $10.4 \mathrm{c}$ & & $6.1 \mathrm{a}$ & $21.3 \mathrm{a}$ \\
Imazalil $250 \mathrm{ppm}$ & $11.2 \mathrm{~b}$ & $22.1 \mathrm{~b}$ & & $0 \mathrm{~b}$ & $4.4 \mathrm{~b}$ \\
Imazalil $500 \mathrm{ppm}$ & $5.2 \mathrm{bc}$ & $9.9 \mathrm{c}$ & & $0 \mathrm{~b}$ & $5.2 \mathrm{~b}$ \\
Imazalil $1,000 \mathrm{ppm}$ & $7.7 \mathrm{~b}$ & $10.2 \mathrm{c}$ & & $0 \mathrm{~b}$ & $4.7 \mathrm{~b}$ \\
Packingline drip method & & & & & \\
Control $\left(21^{\circ} \mathrm{C}\right)$ & $58.7 \mathrm{a}$ & $84.6 \mathrm{a}$ & & $0 \mathrm{~b}$ & $5.3 \mathrm{~b}$ \\
Curing $\left(35^{\circ} \mathrm{C}\right.$ for $\left.48 \mathrm{~h}\right)$ & $0 \mathrm{~d}$ & $11.9 \mathrm{~d}$ & & $4.0 \mathrm{a}$ & $22.3 \mathrm{a}$ \\
Imazalil, 250 ppm & $22.1 \mathrm{c}$ & $47.8 \mathrm{~b}$ & & $0 \mathrm{~b}$ & $9.0 \mathrm{~b}$ \\
Imazalil, $500 \mathrm{ppm}$ & $12.2 \mathrm{c}$ & $32.5 \mathrm{c}$ & & $0 \mathrm{~b}$ & $5.0 \mathrm{~b}$ \\
Imazalil, $1,000 \mathrm{ppm}$ & $12.2 \mathrm{c}$ & $27.4 \mathrm{c}$ & & $0 \mathrm{~b}$ & $8.7 \mathrm{~b}$ \\
\hline
\end{tabular}

${ }^{\text {w }}$ Stored at $21^{\circ} \mathrm{C}$.

${ }^{x}$ Fruit inoculated for green mold and field infection used for stem-end rot.

${ }^{y}$ Means with the same letter in the same column and test are not significantly different based on Duncan's multiple range test $(P=0.05)$.

${ }^{\mathrm{z}}$ Not treated with imazalil.

Table 5. Efficacy of curing and thiabendazole (TBZ) drench on green mold and stem-end rot control using wounded 'Valencia' oranges

\begin{tabular}{lccrrrrrr}
\hline & \multicolumn{3}{c}{ Cumulative green mold (\%) } & & \multicolumn{3}{c}{ Cumulative stem-end rot (\%) } \\
\cline { 2 - 3 } Treatment $^{\mathbf{y}}$ & Week 1 & Week 2 & Week 3 & & Week 1 & Week 2 & Week 3 \\
\hline Control (no curing) & $17.3 \mathrm{a}^{\mathrm{z}}$ & $25.5 \mathrm{a}$ & $29.6 \mathrm{a}$ & & $3.6 \mathrm{~b}$ & $9.1 \mathrm{~b}$ & $10.9 \mathrm{~b}$ \\
Curing & $0 \mathrm{~b}$ & $0 \mathrm{~b}$ & $1.2 \mathrm{~b}$ & & $15.5 \mathrm{a}$ & $21.8 \mathrm{a}$ & $24.3 \mathrm{a}$ \\
TBZ drench plus curing & $0 \mathrm{~b}$ & $0 \mathrm{~b}$ & $0.3 \mathrm{~b}$ & & $0 \mathrm{c}$ & $0.7 \mathrm{c}$ & $0.7 \mathrm{c}$ \\
\hline
\end{tabular}

${ }^{x}$ Stored at $21^{\circ} \mathrm{C}$.

${ }^{y}$ Cured at $35^{\circ} \mathrm{C}$ for $48 \mathrm{~h}$.

${ }^{z}$ Means with the same letter in the same column are not significantly different based on Duncan's multiple range test $(P=0.05)$.

Table 6. Effects of curing and thiabendazole (TBZ) drench on green mold and stem-end rot on 'Flame' grapefruit

\begin{tabular}{lccccccc}
\hline & \multicolumn{2}{c}{ Cumulative green mold $(\%)^{\mathbf{x}}$} & & \multicolumn{3}{c}{ Cumulative stem-end rot (\%) } \\
\cline { 2 - 3 } Treatment $^{\mathbf{y}}$ & Week 1 & Week 2 & Week 3 & & Week 1 & Week 2 & Week 3 \\
\hline Control (no curing) & $58.3 \mathrm{a}^{\mathrm{z}}$ & $64.2 \mathrm{a}$ & $64.2 \mathrm{a}$ & & 0 & $0 \mathrm{a}$ & $0.8 \mathrm{a}$ \\
Curing & $0 \mathrm{~b}$ & $0 \mathrm{~b}$ & $0.8 \mathrm{~b}$ & & 0 & $0.8 \mathrm{a}$ & $2.5 \mathrm{a}$ \\
TBZ drench & $1.7 \mathrm{~b}$ & $2.5 \mathrm{~b}$ & $3.3 \mathrm{~b}$ & & 0 & $0 \mathrm{a}$ & $0 \mathrm{a}$ \\
TBZ drench plus curing & $0 \mathrm{~b}$ & $0 \mathrm{~b}$ & $0 \mathrm{~b}$ & & 0 & $0 \mathrm{a}$ & $0 \mathrm{a}$ \\
\hline
\end{tabular}

${ }^{\mathrm{x}}$ Penicillium digitatum-inoculated grapefruit and no inoculation for stem-end rot. Stored at $21^{\circ} \mathrm{C}$.

${ }^{y}$ Curing conducted at $35^{\circ} \mathrm{C}$ for $48 \mathrm{~h}$.

${ }^{\mathrm{z}}$ Means with the same letter in the same column and test are not significantly different based on Duncan's multiple range test $(P=0.05)$. to control green mold. However, in the current study, we demonstrated that curing fruit at $30^{\circ} \mathrm{C}$ significantly reduced the incidence of green mold, but curing at $35^{\circ} \mathrm{C}$ was even better. Plaza et al. (20) reported that curing 'Navelina' and 'Salustiana' oranges at $30^{\circ} \mathrm{C}$ did not significantly reduce green mold; however, the disease was significantly reduced at $33^{\circ} \mathrm{C}$. Investigations with 'Star Ruby' grapefruit have shown that curing fruit $36 \mathrm{~h}$ postinoculation of $P$. digitatum at $37^{\circ} \mathrm{C}$ for $72 \mathrm{~h}$ effectively controlled decay during 30 days of storage at $8^{\circ} \mathrm{C}$ and a subsequent week of simulated shelf-life conditions at $20^{\circ} \mathrm{C}$ (8). Ben-Yehoshua et al. (2) demonstrated that curing of seal-packaged fruit at $36^{\circ} \mathrm{C}$ and saturated humidity for 3 days effectively reduced decay without any damage to various citrus fruit species during storage at $17^{\circ} \mathrm{C}$ for 35 days.

In the current study, we demonstrated that the duration of curing greatly affected the curing efficacy for green mold control. Curing at $35^{\circ} \mathrm{C}$ for 48 to $72 \mathrm{~h}$ was better for green mold control than times less than $48 \mathrm{~h}$ (Table 3). Considering the cost and possible adverse effects of prolonged curing, the optimum curing conditions for Florida citrus seem to be $35^{\circ} \mathrm{C}$ and 95 to $100 \% \mathrm{RH}$ for $48 \mathrm{~h}$. This is similar or only slightly different from previous reports from other citrus growing regions. It appears that curing fruit at $35^{\circ} \mathrm{C}$ and at least $95 \% \mathrm{RH}$ for $48 \mathrm{~h}$ in the months (January to June) after the Florida degreening season ends could greatly reduce green mold, and the cost of the curing would be minimal when compared to the advantage gained.

Curing 'Pineapple' oranges at $35^{\circ} \mathrm{C}$ for $48 \mathrm{~h}$ showed a similar or better efficacy for green mold control than imazalil at 500 and 1,000 ppm using both dip and simulated commercial packingline drip methods. However, curing has achieved control of green mold by possibly promoting fruit injury healing and restricting fungal growth, and only affects the injuries that occurred before the curing treatment, and might not impact injuries occurring after curing. Further injuries might occur during the washing, packing, and transporting processes.

High environmental humidity during fruit curing is a critical factor for a successful curing treatment for green mold control and maintenance of fruit quality $(3,13)$. The high $\mathrm{RH}$ could play at least two roles during fruit curing: (i) reduce fruit weight loss, and (ii) possibly promote fruit injury healing. Brown (3) reported that degreening for 2 or 3 days at 90 to $96 \% \mathrm{RH}$ and $30^{\circ} \mathrm{C}$ induced lignin formation in injured flavedo tissue of 'Valencia', 'Hamlin', and 'Pineapple' oranges. Lignification rendered the injuries less susceptible to infection by $P$. digitatum, and no lignification occurred when injured fruit were degreened at 55 to $77 \% \mathrm{RH}$ at $30^{\circ} \mathrm{C}$, and consequently fruit were much more 
readily invaded by this fungus (3). Degreening at 90 to $96 \% \mathrm{RH}$ at $27^{\circ} \mathrm{C}$ did not reduce infection by $P$. digitatum as effectively as degreening at $30^{\circ} \mathrm{C}$ and 90 to $96 \%$ RH (3).

Mechanisms for green mold control by fruit curing might include three modes of action: (i) high temperature might directly suppress and reduce the mycelial growth and sporulation of $P$. digitatum, (ii) fruit injuries might be healed, and (iii) phytoalexins might be produced at fruit injury sites at high temperature and humidity. In the current study, $P$. digitatum showed in vitro an optimum growth at about $25^{\circ} \mathrm{C}$, a little growth $\left(78.3 \%\right.$ less than that at $\left.25^{\circ} \mathrm{C}\right)$ at $30^{\circ} \mathrm{C}$, and no growth at $35^{\circ} \mathrm{C}$. These results were similar to those reported by others (2,19). The effective control of green mold by curing at $35^{\circ} \mathrm{C}$ for $48 \mathrm{~h}$ with the high RH (at least $95 \%$ ), in our current study, might be due to the direct suppression of $P$. digitatum growth and the reduction of fruit wound susceptibility to the pathogen by high temperature. Ismail and Brown (16) reported a marked increase in the activity of phenylalanine ammonialyase (PAL) in injured flavedo of 'Valencia' oranges within $72 \mathrm{~h}$ at $30^{\circ} \mathrm{C}$ and $96 \%$ $\mathrm{RH}$, while the activity of PAL did not change in noninjured flavedo tissues. They (17) also reported that free phenolic compounds increased by $100 \%$ in $72 \mathrm{~h}$ when injured 'Valencia' fruit were held at $30^{\circ} \mathrm{C}$ at 90 to $96 \% \mathrm{RH}$ compared with only a $25 \%$ increase in fruit held at $5{ }^{\circ} \mathrm{C}$. The increase of PAL activity is responsible for the increase in lignin and free phenolic constituents in injured citrus flavedo. Lignin formation provides a mechanical barrier that retards or inhibits the penetration of injured tissue by $P$. digitatum (4). In addition to lignification, phytoalexins such as umbeliferone and scoparone have been found at higher levels in cured 'Goliath' pomelo fruit $\left(33\right.$ or $36^{\circ} \mathrm{C}$ ) compared with noncured fruit (2).

In the current study, the curing conditions $\left(35^{\circ} \mathrm{C}\right.$ for $48 \mathrm{~h}$ with at least $95 \% \mathrm{RH}$ ) did not cause any visual physical damage or peel injury on 'Valencia' oranges and 'Flame' grapefruit. However, the curing conditions did cause some peel disorders on 'Pineapple' oranges after 1 week of storage at $21^{\circ} \mathrm{C}$ (J. Zhang, unpublished). These peel disorders further led fruit to become more vulnerable to pathogen infections. In our study, white grapefruit and 'Murcott' tangerines that were also cured at $35^{\circ} \mathrm{C}$ for $48 \mathrm{~h}$ with at least $95 \% \mathrm{RH}$ did not show any heat damage of the fruit peel during the subsequent 3 weeks of storage at $21^{\circ} \mathrm{C}$ (J. Zhang, unpublished). This information indicates that the current curing conditions might not be applicable to some citrus varieties such as 'Pineapple' oranges, and further tests on other citrus varieties are needed.

Plaza et al. (20) reported that curing 'Navelina' and 'Salustiana' oranges at $33^{\circ} \mathrm{C}$ for $65 \mathrm{~h}$ increased weight and firmness loss and reduced the color index and citric acid content, thus increasing total soluble solids/total acid ratio, but had no effect on juice yield and soluble solid levels. A current preliminary study of cured 'Valencia' fruit indicated that fruit taste qualities were not altered in fruit cured at $35^{\circ} \mathrm{C}$ for up to $72 \mathrm{~h}$ (J. Zhang, unpublished). Shirra et al. (22) reported that curing four blood orange varieties, 'Tarocco', 'Moro', 'Sanguinello', and 'Doppio sanguigno', at $37^{\circ} \mathrm{C}$ for $48 \mathrm{~h}$ before cold quarantine at $1^{\circ} \mathrm{C}$ for 16 days, subsequent storage at $8^{\circ} \mathrm{C}$ for 3 days, and an additional week at $20^{\circ} \mathrm{C}$, significantly decreased fruit firmness and adversely affected internal fruit quality. Further research is needed to determine the effects of the current curing conditions $\left(35^{\circ} \mathrm{C}\right.$ for 48 h) on the internal quality and fruit firmness of Florida citrus fruit during curing and the subsequent storage period.

Citrus fruit curing could be effective for the control of certain diseases such as green mold, but it might have adverse effects on other diseases. Our current data clearly indicated that curing temperatures of 30 to $35^{\circ} \mathrm{C}$ significantly reduced green mold, but increased stem-end rot caused by L. theobromae, which is another of the leading postharvest diseases on Florida citrus. Although the increase of stem-end rot by ethylene degreening treatment has been well documented $(1,6,13)$, there is little published information regarding the increase of stem-end rot by high temperature treatment alone. The increase of stemend rot caused by higher temperature might be partially due to the different optimal and tolerance ranges of temperatures for $P$. digitatum and $L$. theobromae growth. Our data indicated that at $35^{\circ} \mathrm{C}$ the growth of $P$. digitatum stopped, but $L$. theobromae still grew well. Ben-Yehoshua et al. (2) also found that $P$. digitatum stopped growing at $34^{\circ} \mathrm{C}$, but $L$. theobromae kept growing even at $40^{\circ} \mathrm{C}$. When wounded fruit were used in some of our tests, a significant increase of $L$. theobromae woundmediated infections was also observed (J. Zhang, unpublished). This might be partially explained by high temperatures' promotion of the growth of L. theobromae, followed by fungus infecting wounds before injuries were healed, or possibly the fungus could directly penetrate the healed injuries. High temperature alone might also affect the fruit physiologically, allowing easier formation of the abscission zone between the fruit and button, thus allowing $L$. theobromae to infect fruit tissue, or to make the fruit more vulnerable (reduced natural fruit resistance) to fungal infections. Some other postharvest diseases such as stem-end rot, caused by Diaporthe citri F.A. Wolf (anamorph Phomopsis citri H. Fawc. non Sacc. Traverso \& Specssa), and sour rot (Galactomyces citri-aurantii E.E. Butler (anamorph Geotrichum citri- aurantii (Ferraris) Butler) were observed in a few tests, but they occurred at a very low level (less than 1\%).

The increase of stem-end rot with curing treatment poses a major problem for using a curing method for green mold control on Florida citrus fruit. However, tests using a combination of chemical and curing treatment to control both green mold and stemend rot were conducted in this study. The procedure was to drench fruit with $\mathrm{TBZ}$ $(500 \mathrm{ppm})$ and then cure the fruit at $35^{\circ} \mathrm{C}$ for $48 \mathrm{~h}$ before fruit were subjected to a normal packing process. TBZ is a registered and effective fungicide for postharvest decay control. L. theobromae is a latent infection pathogen on fruit in citrus groves, and it does not cause fruit decay before harvest. This pathogen causes stemend rot after harvest. Postharvest ethylene degreening or high temperature treatments could enhance the incidence and severity of stem-end rot. Our data indicated that fruit drench with TBZ followed by curing at $35^{\circ} \mathrm{C}$ for $48 \mathrm{~h}$ reduced both stem-end rot and green mold to a commercially acceptable level. Since TBZ drench is a common commercial practice for citrus postharvest decay control in Florida packinghouses, the combination of TBZ drench and curing could be easily adopted in the Florida packing system. In addition, an alternative treatment to TBZ drench might be imazalil drench or preharvest application of thiophanate methyl (Topsin-M) at the rate of $2 \mathrm{lb} / \mathrm{acre}(2.24$ $\mathrm{kg} / \mathrm{ha}$ ). Both imazalil and thiophanate methyl could also be effective for stemend rot control. Imazalil and thiophanate methyl are registered chemicals for citrus postharvest and preharvest applications, respectively.

Florida packinghouses generally degreen fruit with ethylene at 28 to $30^{\circ} \mathrm{C}$ and 90 to $96 \% \mathrm{RH}$ for various time periods to meet the market requirements for coloration. This practice is common for early harvested fruit with natural orange color insufficient to meet market acceptance due to high chlorophyll content in the peel. Obviously, this degreening practice is already a curing treatment because of the use of about $30^{\circ} \mathrm{C}$. Therefore, we suggest if fruit need to be degreened, it is not necessary to conduct an additional curing at $35^{\circ} \mathrm{C}$ for $48 \mathrm{~h}$ since an additional curing time could further enhance stem-end rot and increase the packing cost, fruit weight loss, and heat damage. However, once the degreening season is over, it appears to be beneficial to drench fruit with TBZ followed by curing at $35^{\circ} \mathrm{C}$ for $48 \mathrm{~h}$ before packing to control both green mold and stem-end rot. Packingline application of fungicides could be optional or at lower concentration than standard conventional rates. This technique could be easily adopted into the Florida packing system using existing degreening rooms in packinghouses. 


\section{LITERATURE CITED}

1. Barmore, C. R., and Brown, G. E. 1985. Influence of ethylene on increased susceptibility of oranges to Diplodia natalensis. Plant Dis. 69:228-230.

2. Ben-Yehoshua, S., Shapiro, B., and Moran, R. 1987. Individual seal-packaging enables the use of curing at high temperatures to reduce decay and heal injury of citrus fruits. HortScience 22:777-783.

3. Brown, G. E. 1973. Development of green mold in degreened oranges. Phytopathology 63:1104-1107.

4. Brown, G. E., and Barmore, C. R. 1983. Resistance of healed citrus exocarp to penetration by Penicillium digitatum. Phytopathology 73:691-694.

5. Brown, G. E., and Eckert, J. W. 2000. Diplodia stem-end rot. Pages 43-44 in: Compendium of Citrus Diseases, 2nd ed. L. W. Timmer, S. M. Gernsey, and J. H. Graham, eds. American Phytopathological Society, St. Paul, MN.

6. Brown, G. E., and Lee, H. S. 1993. Interactions of ethylene with citrus stem-end rot caused by Diplodia natalensis. Phytopathology 83:1204-1208.

7. Brown, G. E., and Miller, W. R. 1999. Maintaining fruit health after harvest. Pages 175192 in: Citrus Healthy Management. L. W. Timmer and L. W. Duncan, eds. American Phytopathological Society, St. Paul, MN.

8. D'hallewin, G., Dettori, S., Marceddu, S., and Schirra, M. 1997. Evoluzione dei processi infettivi di Penicillium digitatum Sacc. in vivo e in vitro dopo immersione in acqua calda. Italus Hortus 4:23-26.

9. Eckert, J. W., and Brown, G. E. 1986. Evalua- tion of postharvest fungicide treatments for citrus fruits. Pages 92-97 in: Methods for Evaluating Pesticides for Control of Plant Pathogens. K. D. Hickey, ed. American Phytopathological Society, Paul, MN.

10. Eckert, J. W., and Brown, G. E. 2000. Green mold. Pages 41-42 in: Compendium of Citrus Diseases. 2nd ed. L. W. Timmer, S. M. Gernsey, and J. H. Graham, eds. American Phytopathological Society, St. Paul, MN.

11. Fawcett, H. S. 1922. Packinghouse control of brown rot. Citrograph 7:232-234.

12. Fawcett, H. S., and Barger, W. R. 1927. Relation of temperature to growth of Penicillium italicum and $P$. digitatum and to citrus decay produced by these fungi. J. Agric. Res. 35:925931.

13. Grierson, W., Cohen, E., and Kitagawa, H. 1986. Degreening. Pages 253-271 in: Fresh Citrus Fruits. W. F. Wardowski, S. Nagy, and W. Grierson, eds. Van Nostrand Reinhold Company, New York.

14. Grierson, W., and Newhall, W. F. 1953. Degreening conditions for Florida citrus. Proc. Fla. State Hortic. Soc. 66:42-46.

15. Hopkins, E. F., and Loucks, K. W. 1948. A curing procedure for the reduction of mold decay in citrus fruits. Univ. Fla. Agric. Exp. Stn. Bull. 450:1-26.

16. Ismail, M. A., and Brown, G. E. 1975. Postharvest wound healing in citrus fruit: Induction of phenylalanine ammonia-lyase in injured "Valencia" orange flavedo. J. Am. Soc. Hortic. Sci. 104:126-129.

17. Ismail, M. A., and Brown, G. E. 1975. Phenolic content during healing of 'Valencia' orange peel under high humidity. J. Am. Soc.
Hortic. Sci. 100:249-251.

18. Ismail, M. A., and Zhang, J. X. 2004. Postharvest citrus diseases and their control. Outlooks Pest Manag. 15:29-35.

19. Plaza, P., Usall, J., Teixido, N., and Vinas, I. 2003. Effect of water activity and temperature on germination and growth of Penicillium digitatum, P. italicum and Geotrichum candidum. J. Appl. Microbiol. 94:549-554.

20. Plaza, P., Usall, J., Torres, R., Lamarca, N., and Vinas, I. 2003. Control of green and blue mould by curing on oranges during ambient and cold storage. Postharv. Biol. Technol. 28:195-198.

21. Ritenour, M. A., Zhang, J. X., Wardowski, W. F., and Brown, G. E. 2003. Postharvest decay control recommendations for Florida citrus fruit. UF IFAS Ext. Circ. 359A (Revised): 1-6.

22. Schirra, M., Mulas, M., Fadda, A., and Cauli, E. 2004. Cold quarantine responses of blood oranges to postharvest hot water and hot air treatments. Postharv. Biol. Technol. 31:191200.

23. Smilanick, J. L., Margosan, D. A., Mlikota, F., Usall, J., and Michael, I. F. 1999. Control of citrus green mold by carbonate and bicarbonate salts and the influence of commercial postharvest practices on their efficacy. Plant Dis. 83:139-145

24. Stange, R. R., Jr., and Eckert, J. W. 1994. Influence of postharvest handling and surfactants on control of green mold of lemons by curing. Phytopathology 84:612-616.

25. Wardowski, W. F. 1996. Recommendations for degreening Florida fresh citrus fruits. UF IFAS Ext. Circ. 1170:1-3. 